tion, and the work is accompanied by diagrams, and a magnetic chart of Russia. Investigations in this direction have been very active recently in Russia. Besides the work of Tillo, Miller, Scharnhorst, etc., Schwartz has recently published in the 'Russki invalid' important researches on the magnetics of Turkestan, especially of the observatory at Tashkent.

Charles Rabot has finished a reconnoissance of the Norwegian glacial region, known under the general name of Svartisen. This work is the result of several years' explorations, during which the author received the kindly co-operation of the Norwegian general staff. It is based on a series of triangulations, with the details filled in by means of sketches, and photographs taken at determined angles and azimuths. The result shows a region about 125 kilometres long by forty-five kilometres wide, and divided by mountains into four principalg lacial bodies, but which, on the latest charts, is shown as covered by a single dome of ice.

The Military geographical institute of Italy has published a memoir on the mensuration of the area of the kingdom, and a new essay at the same. The figures are as follows in square kilometers:-

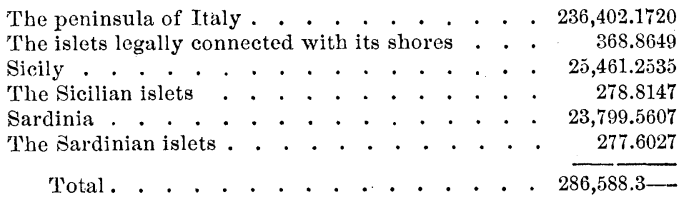
This is about ten thousand square kilometres less than previous official figures, and two thousand less than Gen. Stebnitski's estimate.

The ethnography of the Austrian litorale has been deduced by Baron Carlo von Czoernig from the census of Dec. 31, 1880. The total is six hundred and eleven thousand in round numbers, of which 45.03 per cent are Italians, 32.27 Sloveni, 20.21 Croats, 0.35 Rumanians, and 2.14 German-Austrians, and others. Ethnographically, therefore, these coasts are Slavo-Italian.

Dr. Zélandt has just finished his great work on the Kirgiz, which will be soon published by the west Siberian section of the Imperial geographical society. It is divided into seven heads, treating of the history and archeolooy of Semirechinsk; of the resources of the central Tian-shan; of the life of the nomadic Kirgiz; of their social, commercial, and political institutions; of their ethnic relations; and of their temperament and culture. This work is supplemented by Katanaieff's recent memoir on the progressive movement of the Kirgiz of the Middle Horde, toward the Siberian frontier. A new chart of Russian-Turkestan, scale 1:42000, has just been issued at Tashkent.

It is announced that the work on the commercial geography of China, by Isidore Hedde, has been interrupted by the illness of the author, who has devoted twenty years to it, and was formerly a commercial agent of France in China. Two volumes still remain in manuscript, and will be printed if a sufficient number of subscriptions are received by Paul Perny, care of the Société de géographie, Paris.

Dr. Ten Kate has just sailed for Surinam, with the intention of ascending the river of that name, crossing the Tumuc-kumac mountains, and descending to Brazil by the affluents of the Amazon River.

The recent expedition of Professor Chaffaujon on the Orinoco has been heard from. He had reached Caicara, and had prepared a map of the Orinoco and the region closely adjacent to its banks. In this work he was able to obtain much geological information, and discovered numerous pictorial and graphic aboriginal inscriptions, some of which seemed to be of the nature of writing. An immense mass of ethnological and natural-history collections had been made. Travelling was very expensive, and a large number of men were required to earry on the work.

Father ' $T$. Gaujon writes that Vidal Senèze, who had undertaken an exploration in the Chincha Islands, died at Guayaquil, and his collections were dispersed. The notes of his previous journey from Zumba to Bella Vista, reviewed by several residents of the region, had a certain importance; and the traveller, though without much training, had a spirit and an energy which make his death a loss to science.

A. Chaigneaux is about to take part in an expedition sent out by the Chilian government to the region where Crevaux lost his life, in Bolivia.

\section{A CRAB INVASION.}

AN interesting occurrence, that should be placed on record, has been recently reported by Mr. L. S. Foster of New York, superintendent of the Spanish American district of the American ornithologists' union. It consisted in the sudden appearance of countless myriads of young crabs on the seashore at Cape San Antonio, the western extremity of the Island of Cuba, where it was observed by Francisco Baritista y Ovenes, keeper of the lighthouse at that place. Specimens of the crabs were sent to the U.S. national museum by Mr. Foster, accompanied by the following extract from a letter by the lightkeeper, dated June 14, 1885:-

"After the light of the lighthouse had been extinguished in the morning of April 3, 1885, we went out on the gallery and saw at the edge of the shore, and at intervals farther out, large and small floating patches, of a reddish color, of what appeared to be wood, gulf-weed, or some other vegetable product of the sea. To our surprise, upon inspecting them more closely, we found these patches to consist of small living and moving bodies, belonging to the crabfamily, being of that shape. I proceeded to measure the piles that were forming on the shore, and many of them exceeded one and one-half metres in size [probably diameter']. At eight o'clock in the morning, as more of the patches floated in shore, some of the piles increased to two metres. This multitude of marine animals came from the south-west, the wind and tide being from that direction; and the same phenomenon was repeated on April 9, and May 2 and 
5. They approached the shore mostly during the night, the movement continuing, however, somewhat into the early morning hours. They invaded the houses and the yards, and the tower of the lighthouse up to a certain height, so that we had to brush them away with brooms and shovels, and finally to close the doors and windows, and cover the openings of the water-tanks with canvas and sacking. We lost three tanks of water corrupted by these little creatures. After sunrise they were nearly all killed by the heat, becoming whitish. A few that escaped to the shade lived a few days without growing any larger."

Prof. S. I. Smith of Yale College, to whom the specimens were referred, reports as follows respecting them:-

"The very small crabs from Cape San Antonio, Cuba, are too young and imperfect for precise determination, but are evidently the young, changed from the free-swimming megalops stage of some Grapsoid crab, probably a species of Sesarma. The four specimens are evidently all of the same species. They measure between four and five millimetres in width of carapax."

R. Ratubun.

\section{TYPES OF ETHICAL THEORY.}

Dr. Martineau (it is a pleasure to remember that this country had the honor of giving him his title) has already reached his fourscore years, yet his work shows no sign either of labor or of sorrow. Its characteristics are indeed precisely the reverse of these : they are facility and optimism. There is the same dignified eloquence which made George Eliot write, in 1853, "James Martineau transcends himself in beauty of imagery." There is the same calm faith which has always possessed him in the outcome of the philosophical controversies of the time. For forty years he has stood quite alone among English theists in his breadth of sympathy and his sweep of style; and there is much pathos to many a grateful student in the words with which he dismisses this work, hoping to deal with further problems, "in case the evening twilight of life should linger a little longer with me, and leave my powers of industry still unspent.",

It is impossible to review such a book as this with any completeness, within the limits which must be here observed. It is the ripened fruit of a lifetime, and it must be recognized, as has been done by the Spectator, as the most important ethical work of this generation. It traces the great types of ethical theory, advancing with " many com-

Types of ethical theory. By James Martineau, D.D., LL.D. 2 vols. Oxford, Clarendon press, 1885. panions, stately or keen, severe or facile, mystic or humane," until the view of the author is set in final and striking contrast with that of the so-called English school. Here, to most readers, is the central interest of the book. It is Kantian ethics in the hands of a master of style over against the laborious inadequacy of $\mathrm{Mr}$. Spencer. Nothing can be more delightful than the ease and brilliancy of this discussion, or more honorable than its recognition of the worth of the opposing school. "The representative writers of this school," Mr. Martineau concludes, "have in truth theorized in one language, and felt in another, and have retained ideal conceptions of a scale of good, and admirations for types of character, for which their doctrine can find no corresponding place. Nor is this an accident of their individual presentations of the theory. So long as it sets itself to find the moral in the immoral, to identify the order of right with the order of strength, to repudiate any study of what ought to be except in studying what has been, is, and will be, it totally shuts the door in the face of all conception and possibility of duty, and by naturalizing ethics reverses the idealizing process which rather ethicizes nature. It subjugates character to science, instead of freeing it into religion."

Two sources of embarrassment are here hinted at, which are felt throughout the work. The one is the loyalty of the writer to the terminology of the school in which he has been reared. This is so marked in the presentation of the author's own theory, that the hasty reader may fancy that he is dealing once more with that analysis of faculties which used to satisfy the writers on ethics, and which made the study so dreary. "The virtues and vices, the appetites, emotions, and affections," some one has said of that earlier school, "stood each in its appointed corner, and with its appropriate label. Never before had human nature been so neatly dissected, or so ornamentally packed up." It is not until one has penetrated through this somewhat repelling method, that he discovers the wealth of insight which Dr. Martineau's treatment exhibits. The other source of embarrassment is more serious. It is the obvious conviction of the writer that the principles of ethics cannot be finally described apart from their relation to religion. After all is said and done, human nature remains, as Mr. Bradley most forcibly points out in his ' Ethical studies,' a contradiction whose solution compels one to the religious attitude. Dr. Martineau constantly hints at this necessary incompleteness; and 